\title{
PEMBERIAN FLY ASH (ABU SISA BOILER PABRIK PULP) UNTUK MENINGKATKAN pH TANAH GAMBUT
}

\author{
Rini ${ }^{1}$, Hazli Nurdin ${ }^{2}$, Hamzar Suyani ${ }^{3}$, Teguh B. Prasetyo ${ }^{4}$ \\ ${ }^{1}$ Laboratorium Pendidikan Kimia, MIPA FKIP Universitas Riau, Pekanbaru \\ ${ }^{2}$ Laboratorium Elektrokimia, Jurusan Kimia, FMIPA, Universitas Andalas, Padang \\ ${ }^{3}$ Laboratorium Organik, Jurusan Kimia, FMIPA, Universitas Andalas, Padang \\ ${ }^{4}$ Laboratorium Ilmu tanah, Jurusan Ilmu Tanah, Faperta, Universitas Andalas, padang
}

\begin{abstract}
The research of fly ash as ameliorant to decrease the humic acid in peat soil of Rimbo Panjang, Riau. It is found that fly ash at 10 ton/Ha showed the best result decresing $\mathrm{pH}$ of peat soil (4.4 to 6.36) and humic acid content $(0.2923 \mathrm{~g} / \mathrm{g}$ to $0.0972 \mathrm{~g} / \mathrm{g})$.
\end{abstract}

Keywords: fly ash, peat soil, pH, humic acid

\section{PENDAHULUAN}

Riau adalah propinsi yang mempunyai industri bergerak dalam bidang pulp dan kertas. Ada dua perusahaan pulp dan kertas berskala internasional beroperasi di propinsi Riau yaitu PT. Indah Kiat Pulp and Paper yang mampu memproduksi kertas dan pulp 200 juta ton pertahun dan PT. Riau Andalan Pulp and Paper dengan kapasitas produksi 250-300 ribu ton pulp pertahun.

Kapasitas produksi yang besar sebanding dengan limbah industri yang dihasilkan. Limbah tersebut antara lain adalah sampahsampah organik, limbah cair dan limbah padat. Diantara beberapa bentuk limbah padat produk sisa industri pulp dan kertas adalah fly ash yaitu limbah pabrik dari hasil abu sisa pada boiler pabrik pulp ${ }^{[1]}$. Informasi yang diperoleh dari karyawan pabrik, untuk setiap harinya dihasilkan fly ash sebanyak 200 ton per hari.

Fly ash bersifat basa (mempunyai $\mathrm{pH}$ 10-13) dan mengandung kation-kation yang diperlukan tanaman seperti $\mathrm{Ca}, \mathrm{Mg}, \mathrm{Zn}, \mathrm{K}$, dan $\mathrm{P}$ serta tidak mengandung logam-logam berat yang berbahaya bagi tanah dan tanaman, sehingga dapat dijadikan amelioran untuk memperbaiki sifat kimia tanah khususnya tanah gambut ${ }^{[2]}$.
Riau merupakan salah satu daerah yang memiliki kawasan tanah gambut yang cukup luas. Lahan-lahan yang telah dibuka maupun yang masih tersedia untuk perluasan areal pertanian sebagian besar terdiri dari tanah gambut dan miskin unsur hara. Menurut data statistik 52,63\% dari seluruh dataran di daerah Riau terdiri dari tanah gambut ${ }^{[3]}$.

Pemanfaatan tanah gambut untuk pertanian dihadapkan pada beberapa masalah yaitu: (1) ketebalan dan taraf dekomposisi, (2) status hara makro dan mikro yang rendah, (3) kemasaman tanah dan kandungan asam-asam organik, (4) adanya lapisan pirit, dan (5) tata air yang buruk. Walaupun banyak masalah yang dihadapi, pengalaman menunjukkan bahwa dengan pengelolaan tanah yang tepat, tanah gambut dapat dijadikan lahan yang produktif ${ }^{[4]}$.

Upaya perbaikan tingkat kesuburan tanah gambut telah banyak dilakukan, meliputi: (1) pencucian bahan-bahan beracun ${ }^{[5,6,7]}$, (2) pengapuran dan penambahan bahan ${ }^{[2,8,9,10]}$, (3) penambahan unsur hara makro dan mikro[6,11], (4) penggunaan jenis dan varietas tanaman yang toleran terhadap kemasaman tanah yang tinggi ${ }^{[7,13]}$. Pemecahan masalah pada tanah gambut sudah banyak dilakukan.

Pada prinsipnya memperbaiki kondisi tanah gambut yaitu dengan menaikkan $\mathrm{pH}$ tanah dan 
meningkatkan ketersediaan hara tanaman. Namun cara-cara yang ditempuh kadangkadang dinilai kurang praktis dan kurang diarahkan untuk mengatasi permasalahan utama pada tanah gambut ${ }^{[14]}$.

Permasalahan utama pada tanah gambut untuk pengembangan lahan pertanian adalah kandungan asam-asam organik beracun yang tinggi dan sangat erat hubungannya dengan komposisi bahan organik tanah gambut. Dengan kata lain masalah yang perlu diatasi terlebih dahulu pada tanah gambut adalah asam-asam organik ini. Upaya selanjutnya, setelah dapat mengendalikan asam-asam organik tersebut adalah pemenuhan hara makro maupun mikro bagi tanaman ${ }^{[15]}$.

Kandungan asam-asam organik yang tinggi pada tanah gambut menyebabkan tanah gambut mempunyai $\mathrm{pH}$ yang rendah (bersifat asam). Salah satu asam organik yang terdapat dalam jumlah besar pada tanah gambut adalah asam humat. Asam humat merupakan bagian dari asam organik bersifat asam yang larut dalam basa, namun mengendap dalam asam. Asam humat dapat terbentuk dari organisme khususnya tumbuh-tumbuhan yang telah mati dan terurai menjadi bahan organik tanah.

Secara teoritis, bahan amelioran yang ideal adalah mempunyai sifat-sifat kejenuhan basa tinggi, dapat meningkatkan $\mathrm{pH}$ gambut, serta memiliki kandungan unsur hara yang lengkap, sehingga juga berfungsi sebagai pupuk dan mempunyai kemampuan memperbaiki struktur tanah gambut. Fly ash menjadi salah satu alternatif yang memberi harapan dapat memperbaiki sifat kimiawi tanah gambut sekaligus mampu mengurangi beban limbah terhadap lingkungan.

Fly ash adalah abu sisa boiler pabrik pulp. Material fly ash sendiri berasal dari sisa-sisa chip dan cangkang kelapa sawit. Kandungan asam humat yang berada dalam tanah gambut dapat dinetralisir oleh fly ash yang bersifat basa ( $\mathrm{pH}$ 10-13) sehingga dapat mengurangi kandungan asam humat dalam tanah gambut yang mengakibatkan $\mathrm{pH}$ tanah menjadi naik.

\section{METODOLOGI}

\begin{abstract}
Alat dan Bahan
Alat-alat yang digunakan dalam penelitian ini yaitu: kertas saring whatman 42, pengayak octagen $250 \mu \mathrm{m}$. Lumpang, $\mathrm{pH}$ meter, meteran, alat tulis, timbangan, peralatan gelas, ember, karung, indikator universal, sentrifus dan pipet tetes, dan shaker.
\end{abstract}

Bahan-bahan yang digunakan dalam penelitian ini adalah fly ash yang diperoleh dari PT. IKPP, sampel tanah dari lahan gambut daerah Rimbo Panjang, akuades, larutan $\mathrm{NaOH} 0,1 \mathrm{M}$ dan larutan HCL 0,1 M, dan jagung sebagai tanaman indikator.

\section{Prosedur}

Penelitian dilaksanakan secara eksperimen dengan 1 faktor, 4 perlakuan, dan 3 kali ulangan. Fly ash akan ditabur ke dalam petak percobaan $(50 \mathrm{~cm} \times 40 \mathrm{~cm} \times 50 \mathrm{~cm})$ dengan dosis fly ash sebagai berikut:

Po = Tanpa pemberian Fly ash

$\mathrm{P} 1=$ Diberi Fly ash dengan dosis $50 \mathrm{~g} /$ petak

$\mathrm{P}_{1}=$ Diberi Fly ash dengan dosis $100 \mathrm{~g} /$ petak

$\mathrm{P}_{2}=$ Diberi Fly ash dengan dosis $200 \mathrm{~g} /$ petak

$\mathrm{P}_{3}=$ DiberiFly ash dengan dosis $300 \mathrm{~g} /$ petak

Sebelum dilakukan penelitian dipilih lahan gambut yang mempunyai topografi datar (di Rimbo Panjang Kecamatan Kampar), kemudian lahan digunakan untuk pengambilan tanah penelitian. Bahan gambut diambil secara acak dan dimasukkan ke dalam karung plastik untuk diangkut ke tempat penelitian. Bahan gambut dikeringanginkan selama 1 minggu di tempat teduh (di bawah pohon) dan dibersihkan dari ranting serta akar tanaman. Fly ash diambil dari tempat penampungan (PT. Indah Kiat) kemudian dimasukkan ke dalam karung dan diangkut ke tempat penelitian.

Petak percobaan dibuat dan kayu dengan ukuran panjang $50 \mathrm{~cm}$, lebar $40 \mathrm{~cm}$ dan tinggi $50 \mathrm{~cm}$ sebanyak 12 petak. Tiga petak sebagai kontrol dan 9 petak yang lain diberikan fly ash dengan dosis tertentu.

Bahan gambut yang telah kering angin dibersihkan dari ranting dan akar tanaman, ditimbang sama banyak ( $\pm 32 \mathrm{~kg}$ ) untuk masing-masing petak kemudian dimasukkan ke dalam petak percobaan. Tinggi tanah gambut 
dalam petak percobaan $\pm 40 \mathrm{~cm}$. Dua minggu sebelum penanaman, fly ash ditabur ke dalam petak percobaan sesuai dengan dosis perlakuan. Penaburan fly ash dilakukan merata pada permukaan tanah gambut. Sebagai petunjuk produktifitas tanah, pada penelitian ini digunakan tanaman jagung. Penanaman dilakukan dengan sistem tugal, dimana setiap lobang ditanami 3 biji. Setelah 1 minggu dilakukan penjarangan dengan meninggalkan 1 batang tiap rumpun.

\section{Persiapan Sampel untuk Uji Laboratorium}

Cara pengambilan sampel tanah sangat menentukan keakuratan hasil analisis. Tanah gambut yang telah diberi perlakuan diambil secara acak pada masing-masing plot dengan kedalaman 20-30 cm. Untuk menghindari subjektivitas dalam pengambilan sampel, maka titik pengambilan sampel tanah menyebar merata ke seluruh daerah di dalam plot.

Pengambilan sampel tanah pada masingmasing plot dikumpulkan dalam satu wadah lalu diaduk-aduk hingga merata, selanjutnya diambil $500 \mathrm{~g}$ dan dimasukkan ke dalam kantong plastik. Kemudian setiap kemasan sampel tanah diberi label yang menandakan lokasi pengambilan sampel.

Selanjutnya tanah gambut awal, fly ash dan tanah gambut yang telah diberi perlakuan dikeringanginkan selama seminggu di tempat yang teduh pada udara terbuka. Tanah yang sudah dikeringanginkan digerus lalu diayak dengan pengayak octagon $250 \mu \mathrm{m}$. Sampel tanah yang diperoleh selanjutnya dibawa ke laboratorium untuk dianalisis lebih lanjut.

\section{Uji Laboratorium}

Uji laboratorium meliputi analisis $\mathrm{pH}$ fly ash, $\mathrm{pH}$ tanah gambut, kandungan asam humat fly ash, dan kandungan asam humat gambut. Tahapan analisis bahan gambut meliputi: analisis pra perlakuan, minggu ke-3 (setelah diinkubasi), minggu kesembilan, serta minggu ketiga belas. Analisis pra perlakuan dilakukan untuk mengetahui berapa peningkatan $\mathrm{pH}$, penurunan kandungan asam humat pada tanah gambut setelah perlakuan.

\section{HASIL DAN DISKUSI}

\section{Pertumbuhan Tanaman Indikator}

Tanaman indikator dalam penelitian ini adalah tanaman jagung varietas arjuna. Tanaman jagung varietas arjuna disamping memiliki organ tanam yang lengkap (akar, batang, daun dan buah) juga tahan terhadap penyakit, masa tanam pendek ( 90 hari), dan menghendaki $\mathrm{pH}$ tanah mendekati netral untuk pertumbuhannya ${ }^{[16]}$.

Pertumbuhan tanaman indikator (tanaman jagung) pada perlakuan tanpa fly ash sangat terhambat. Tanaman hanya dapat tumbuh dan bertahan selama 1 minggu. Ini disebabkan oleh $\mathrm{pH}$ tanah gambut yang rendah menyebabkan terhambatnya perpanjangan pertumbuhan akar primer, menghalangi pembentukan akar dan bulu akar serta menghambat sintesis DNA dalam sel akar ${ }^{[17]}$.

Pemberian fly ash $200 \mathrm{~g} /$ petak, pertumbuhan tanaman indikator telah cukup baik. Ini tampak pada organ tumbuh tanaman yang berkembang dengan baik antara lain pertumbuhan akar tanaman panjang dan banyak cabangnya, batangnya tumbuh dengan kokoh dan besar, daunnya lebar dan berwarna hijau, cepat berbunga dan buahnya padat berisi. Hal ini diduga karena $\mathrm{pH}$ tanah sudah mengarah ke netral $(6,36)$, ketersediaan unsur-unsur hara yang dibutuhkan oleh tanaman telah mencukupi untuk pertumbuhannya.

Menurut Lingga dan Marsono $^{[16]}$, derajat keasaman yang baik untuk tanaman jagung adalah 5,5-7,0. Tanaman yang $\mathrm{pH}$-nya kurang dari 5,5 mengakibatkan unsur-unsur mikro (Al, $\mathrm{Fe}, \mathrm{Zn}, \mathrm{Mn}$, dan $\mathrm{Cu}$ ) banyak terlarut sehingga meracuni tanaman. Pada perlakuan fly ash 300 $\mathrm{g} /$ petak, pertumbuhan tanaman indikator tidak berbeda nyata dengan $200 \mathrm{~g} /$ petak. Hanya saja pertumbuhan batangnya lebih subur dan tinggi, tetapi lambat berbunga (minggu ke-9), tongkolnya besar namun buahnya jarang. Hal ini disebabkan oleh kelebihan unsur-unsur hara tertentu sehingga keseimbangan haranya juga terganggu. Ditinjau dari segi efisiensi ekonomi untuk diterapkan pada skala lapangan maka kondisi optimum penambahan fly ash pada perlakuan $200 \mathrm{~g} /$ petak. 


\section{Uji Laboratorium}

Ketersediaan Awal Kandungan Asam Humat dan $\mathrm{pH} \mathrm{H}_{2} \mathrm{O}$ pada Tanah Gambut, Fly Ash

Kandungan asam humat dan $\mathrm{pH}$ tanah gambut di daerah Rimbo Panjang, fly ash dari PT. IKPP sebagai acuan awal penelitian dapat dilihat pada Tabel 1.

Tabel 1 memperlihatkan bahwa tanah gambut di daerah Rimbo Panjang memiliki $\mathrm{pH}$ yang rendah ( $\mathrm{pH}$ kecil dari 4,5) dan kandungan asam humat yang tinggi. Nilai $\mathrm{pH}$ ini hampir sama dengan nilai $\mathrm{pH}$ gambut pada penelitian Amri dan Rosmimi yaitu sebesar 4,5 ${ }^{[18]}$ dan penelitian Rini sebesar 3,2 ${ }^{[10]}$. Hal ini menunjukkan bahwa tanah gambut di daerah Rimbo Panjang mengandung bahan-bahan organik yang tinggi karena masih banyak mengandung serabut-serabut. Pelapukan bahan organik tersebut akan menghasilkan asamasam organik yang menyebabkan tanah gambut menjadi asam dan kejenuhan basa rendah. Berdasarkan sifat kematangannya, gambut di daerah Rimbo Panjang termasuk gambut hemik karena saat digenggam dan diperas hanya $1 / 3$ bagian keluar dari celahcelah jari genggaman ${ }^{[3]}$.

Fly ash memiliki $\mathrm{pH} \mathrm{H}_{2} \mathrm{O}$ yang bersifat basa $(10,437)$ dan tidak mengandung asam humat. Tingginya $\mathrm{pH}$ fly ash disebabkan karena fly ash banyak mengandung kation-kation basa. Kation-kation basa pada fly ash dapat meningkatkan $\mathrm{pH}$ dengan menetralisir asamasam organik yang ada pada bahan gambut.

\section{Nilai pH $\mathrm{H}_{2} \mathrm{O}$ pada Tanah Gambut Setelah Penambahan Fly Ash}

Rata-rata nilai $\mathrm{pH}$ tanah gambut di daerah Rimbo panjang dengan waktu analisis bahan gambut yang dilakukan pada minggu ketiga, kesembilan, dan ketiga belas dengan dosis fly ash Po (0 kg/plot), P1 (50 g/petak), P2(100 $\mathrm{g} /$ petak), P3 (200 g/petak), dan P4 (300 g/petak) dapat dilihat pada Gambar 1.

Tabel 1. Kandungan Asam Humat dan pH Tanah Gambut Awal, Fly Ash

\begin{tabular}{lcc}
\hline \multicolumn{1}{c}{ Sampel } & $\begin{array}{c}\text { Kandungan } \\
\text { Asam humat } \\
\text { (gr/gr) }\end{array}$ & $\mathrm{pH}$ \\
\hline $\begin{array}{l}\text { Tanah Gambut Awal } \\
\text { Fly ash }\end{array}$ & 0,2923 & 4,357 \\
& - & 10,437
\end{tabular}

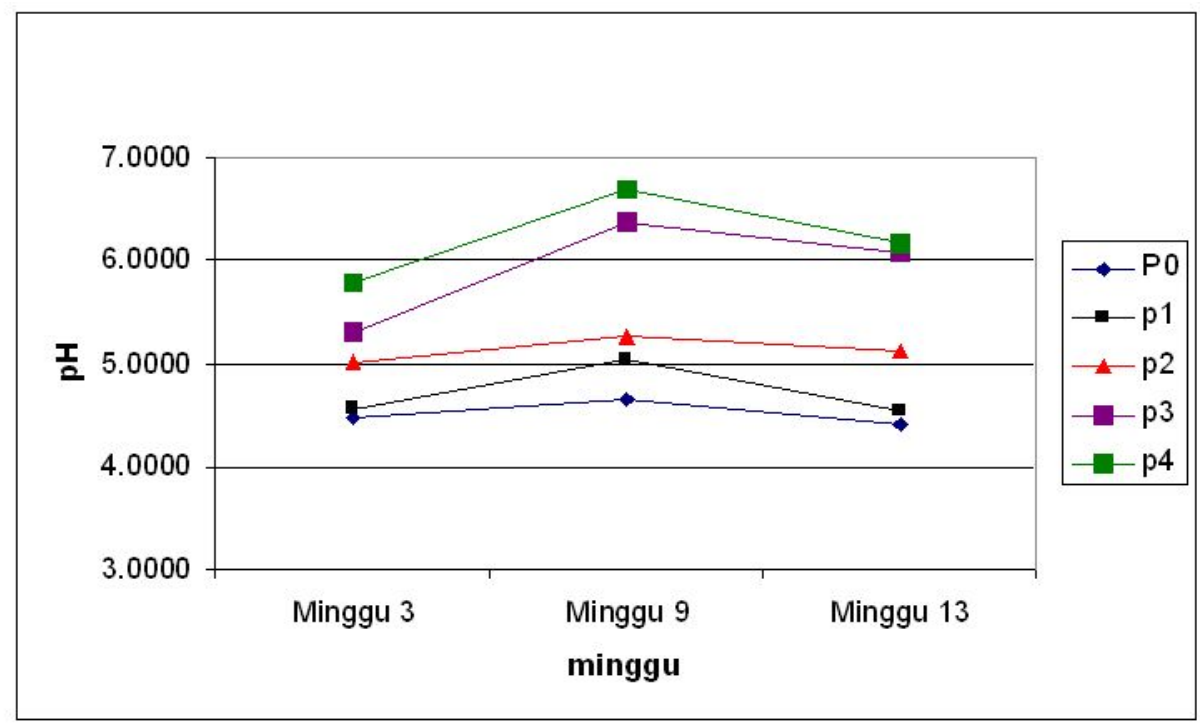

Gambar 1. Hubungan $\mathrm{pH}$ tanah gambut dengan dosis fly ash yang berbeda selama penelitian Po $(0 \mathrm{~kg} / \mathrm{plot})$, P1 (50 g/petak), P2(100 g/petak), P3 (200 g/petak), dan P4 (300 g/petak) 
Dari pengamatan $\mathrm{pH} \mathrm{H}_{2} \mathrm{O}$ awal, lahan gambut di daerah Rimbo Panjang memiliki $\mathrm{pH} \mathrm{H}_{2} \mathrm{O}$ yang tergolong asam. Keasaman lahan gambut berasal dari $\mathrm{H}^{+}$yang dapat dipertukarkan dan $\mathrm{H}^{+}$(aktif) larutan. Ion $\mathrm{H}^{+}$tersebut berada dalam keadaan seimbang dalam larutan tanah sehingga menyebabkan $\mathrm{pH}$ larutan menjadi rendah $^{[19]}$.

Analisa $\mathrm{pH} \quad \mathrm{H}_{2} \mathrm{O}$ dilakukan untuk setiap perlakuan pada minggu ketiga setelah fly ash serta minggu kesembilan dan ketiga belas. Dari penelitian didapatkan bahwa penambahan fly ash yang bersifat basa dapat meningkatkan $\mathrm{pH}$ tanah gambut. Peningkatan $\mathrm{pH}$ pada penelitian ini adalah sebesar 2,3 satuan $\mathrm{pH}$. Menurut Foth $^{[17]}$, peningkatan nilai $\mathrm{pH}$ terjadi karena jumlah $\mathrm{H}^{+}$yang terlarut dinetralisasi oleh ion $\mathrm{OH}^{-}$yang berasal dari hidrolisis kation-kation basa yang terdapat pada fly ash, terutama kalsium dan sebagian $\mathrm{H}^{+}$yang dapat dipertukarkan terionisasi untuk mengembalikan keadaan yang seimbang. Jumlah $\mathrm{H}^{+}$yang dipertukarkan akan berkurang dengan perlahan-lahan sehingga $\mathrm{H}^{+}$terlarut akan menurun dan $\mathrm{pH}$ akan meningkat dengan perlahan. Bila amelioran diberikan ke dalam tanah, kemungkinan ia bereaksi adalah dengan air dan dengan koloid tanah ${ }^{[9]}$.

Reaksi fly ash yang mengandung kation-kation basa yang dibutuhkan tanaman, seperti kalsium dengan air dapat digambarkan sebagai berikut:[20]

$\mathrm{CaCO}_{3}+\mathrm{H}_{2} \mathrm{O} \longrightarrow \mathrm{Ca}^{2+}+\mathrm{HCO}_{3}{ }^{-}+\mathrm{OH}^{-}$

Dari reaksi hidrolisa ini akan disumbangkan ion $\mathrm{OH}^{-}$sehingga $\mathrm{pH}$ lahan gambut mengalami peningkatan.

Peningkatan $\mathrm{pH}$ juga terjadi karena kationkation basa, seperti kalsium pada fly ash mengalami pertukaran kation dengan koloid tanah (misel) yang banyak menyerap asamasam organik seperti asam humat. Reaksi pertukaran kation tersebut dapat digambarkan sebagai berikut:[21]

$$
\begin{aligned}
& \mathrm{H}-\text { Misel- } \mathrm{H}+\mathrm{CaCO}_{3} \rightleftarrows \text { Ca-Misel }+ \\
& \mathrm{H}_{2} \mathrm{O}+\mathrm{CO}_{2}
\end{aligned}
$$

Akibat adanya adsorpsi kalsium tersebut, maka persentase kejenuhan basa dari kompleks adsorpsi akan naik. Dengan demikian $\mathrm{pH}$ larutan tanah juga akan meningkat. Hal ini dimungkinkan karena basa-basa dari fly ash telah bereaksi dengan $\mathrm{H}^{+}$yang merupakan sumber keasaman lahan gambut yang dapat berasal dari asam-asam organik seperti asam humat. Pada dosis fly ash Po, $\mathrm{pH}$ tanah gambut di daerah Rimbo Panjang juga mengalami sedikit peningkatan, namun peningkatannya tidak begitu nyata yaitu sebesar 0,106 . Hal ini disebabkan oleh jumlah kation-kation basa pada lahan gambut hanya sedikit karena tidak ada sumbangan kation-kation basa dari fly ash.

Pada penambahan dosis fly ash $\mathrm{P}_{1}, \mathrm{P}_{2}, \mathrm{P}_{3}$, dan $\mathrm{P}_{4}$ terjadi peningkatan nilai $\mathrm{pH}$ pada waktu analisa bahan gambut minggu ketiga dan kesembilan. Peningkatan nilai $\mathrm{pH}$ sesuai dengan dosis fly ash yang diberikan, dimana peningkatan tertinggi diperoleh pada dosis $\mathrm{P} 4$. Hal ini sesuai dengan teori yang dikemukakan oleh Pathan ${ }^{[9]}$ bahwa perubahan $\mathrm{pH}$ akan nyata apabila diberikan cukup amelioran sehingga seluruh ion $\mathrm{H}^{+}$yang terserap dapat digantikan oleh kation-kation basa, terutama oleh kation $\mathrm{Ca}^{2+}$.

Fly ash yang bersifat sukar larut akan semakin bereaksi dengan tanah gambut sebanding dengan lamanya waktu pengambilan sampel bahan gambut karena kation-kation basa $\mathrm{Ca}^{2+}$ dan $\mathrm{Mg}^{2+}$ yang terdapat dalam fly ash akan lebih banyak mengalami pertukaran dengan ion $\mathrm{H}^{+}$yang ada dalam larutan tanah. Selain itu, adanya sumbangan kation-kation basa dari fly ash mengikat butir-butir tanah menyebabkan kejenuhan basa tanah gambut akan semakin tinggi karena pencucian kation-kation basa akan berkurang. Kejenuhan basa berhubungan erat dengan $\mathrm{pH}$ dimana lahan dengan $\mathrm{pH}$ rendah umumnya mempunyai kejenuhan basa rendah, sedangkan lahan dengan $\mathrm{pH}$ yang tinggi mempunyai kejenuhan basa yang tinggi pula $^{[22]}$.

Pada minggu ketiga belas untuk semua perlakuan terjadi penurunan nilai $\mathrm{pH}$ bila dibandingkan dengan analisa minggu kesembilan. Hal ini terjadi karena kationkation basa dan unsur-unsur hara lainnya telah diserap tanaman dalam jumlah yang besar untuk pertumbuhan dan sebagian ada yang hilang tercuci oleh air, sehingga terjadi pertukaran kation-kation basa, seperti $\mathrm{Ca}^{2+}$ 
dengan ion $\mathrm{H}^{+}$pada koloid tanah. Reaksinya dapat digambarkan sebagai berikut :

\section{Misel-Ca $+2 \mathrm{H}^{+} \rightleftarrows$ Misel-2H $+\mathrm{Ca}^{2+}$}

Hal ini sesuai dengan penelitian Ritchey dan Snuffer bahwa pada saat panen kation-kation basa terangkut oleh tanaman baik di dalam biji maupun serasah tanaman sehingga $\mathrm{pH}$ tanah mengalami penurunan ${ }^{[23]}$. Hal ini juga sesuai dengan pendapat Pathan, yang mengatakan bahwa pertukaran kation-kation basa, seperti $\mathrm{Ca}^{2+}$ dengan ion $\mathrm{H}^{+}$berlangsung secara ekuivalen. Apabila terjadi penurunan ion $\mathrm{H}^{+}$ atau terjadi penambahan ion $\mathrm{Ca}^{2+}$, maka reaksi akan beralih ke kiri. Sebaliknya, jika terjadi penambahan ion $\mathrm{H}^{+}$atau terjadi penurunan ion $\mathrm{Ca}^{2+}$, maka reaksi akan beralih ke kanan, sehingga menyebabkan $\mathrm{pH}$ tanah gambut sedikit mengalami penurunan ${ }^{[9]}$.

\section{Spektrum Infra Merah Asam Humat}

Sebelum ditentukan konsentrasinya, asam humat yang diperoleh melalui metode ekstraksi dan gravimetri yang dikembangkan oleh Tan terlebih dahulu dikarakterisasi dengan spektrofotometer infra merah. Ini bertujuan untuk memastikan bahwa ekstrak yang diperoleh adalah benar asam humat. Hasil pengukuran asam humat dengan spektrofotometer infra merah dapat dilihat pada Gambar 2.

Hasil pengukuran asam humat menggunakan spektrofotometer infra merah menunjukkan bahwa gambar yang diperoleh sesuai dengan spektrum infra merah diperoleh dari literatur sebagai acuan.

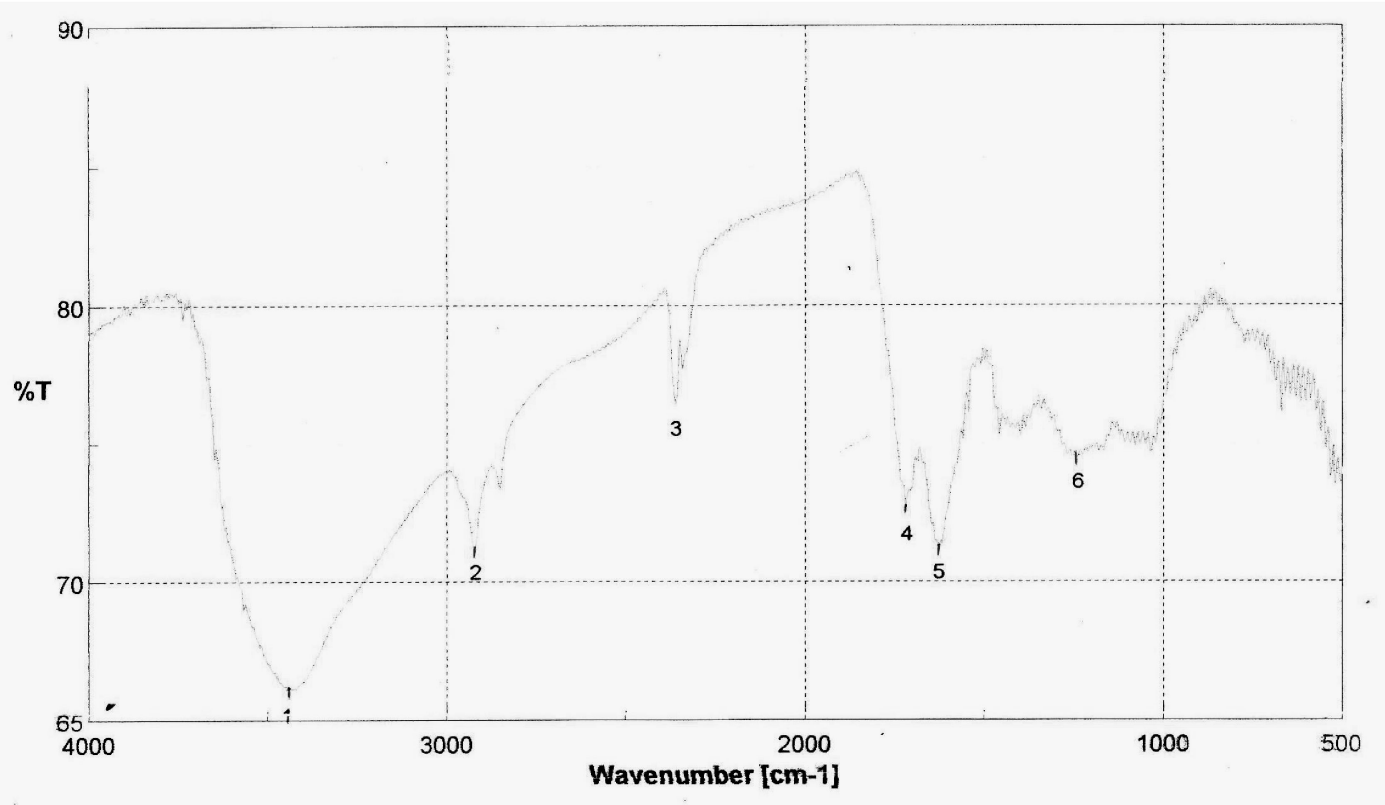

Gambar 2. Spektrum infra merah dari asam humat pada tanah gambut

Tabel 2. Gugus Fungsionil asam humat menggunakan Spektofotometer Infra Merah

\begin{tabular}{lc}
\hline \multicolumn{1}{c}{ Gugus Fungsionil } & Panjang Gelombang $\left(\mathrm{CM}^{-1}\right)$ \\
\hline Peregangan $\mathrm{O}-\mathrm{H}$ dan N-H & 3400 \\
Peregangan C-H & 2931 \\
Peregangan C-O dari gugus Karboksil & 1713 \\
Peregangan C=O aromatik, C =O ikatan ganda yang & 1625 \\
terkonjugasi dengan fibrasi karbonil & \\
\hline
\end{tabular}




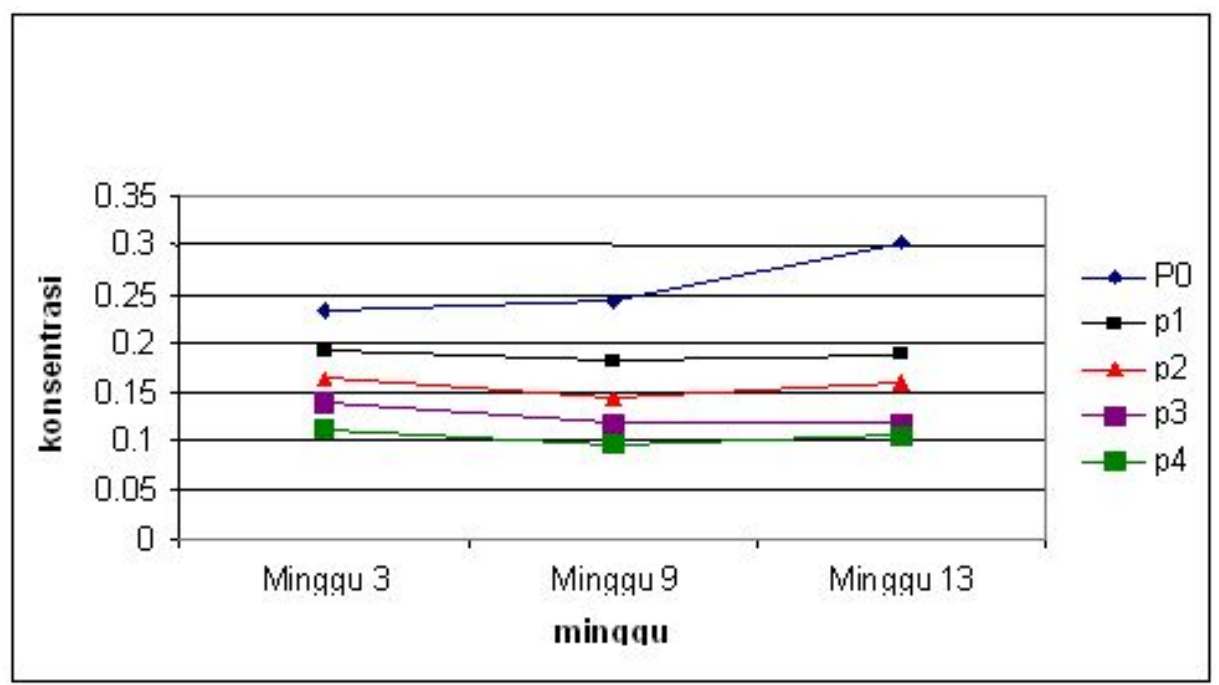

Gambar 3. Hubungan konsentrasi asam humat tanah gambut dengan dosis fly ash yang berbeda selama penelitian o (0 kg/plot), P1 (50 g/petak), P2(100 g/petak), P3 (200 g/petak), dan P4 (300 g/petak)

\section{Kandungan Asam Humat Bahan Gambut Setelah Penambahan Fly Ash}

Pengaruh penambahan fly ash terhadap kandungan asam humat tanah gambut dapat dilihat pada Gambar 3.

Gambar 3 memperlihatkan bahwa pada plot yang tidak diberi fly ash kandungan asam humat dari minggu ke 3 sampai minggu ke 13 mengalami peningkatan, yaitu dari $0,2342 \mathrm{~g} / \mathrm{g}$ di minggu ke 3;0,2413 g/g di minggu ke 9 dan mencapai $0,3038 \mathrm{~g} / \mathrm{g}$ di minggu ke 13 . Hal ini disebabkan karena tidak adanya sumbangan kation basa dari amelioran fly ash yang diharapkan dapat menetralisir sebagian asam humat yang terdapat pada tanah gambut. Dan hal ini juga menyebabkan $\mathrm{pH}$ tanah menjadi asam.

Pada minggu ke 3 dan minggu ke 9 pemberian dosis fly ash P1 (50 g/petak), P2 (100 g/petak), P3 (200 g/petak), dan P4 (300 g/petak) terlihat bahwa kandungan asam humat terus menurun dengan bertambahnya amelioran dregs yang diberikan karena semakin banyak fly ash yang diberikan maka semakin banyak kation basa yang disumbangkan untuk menetralkan gugus asam yang terdapat pada asam humat sehingga kadar asam humat menjadi berkurang.

Pada minggu ke 13 kandungan asam humat mengalami peningkatan dibandingkan pada minggu ke 3 dan ke 9 karena sebagian kation basa terangkut oleh tanaman dan ada yang hilang tercuci oleh air, juga terjadi proses dekomposisi asam-asam organik pada tanah sehingga asam humat menjadi bertambah.

\section{KESIMPULAN}

Pemberian amelioran fly ash pada tanah gambut dapat meningkatkan nilai $\mathrm{pH}$ dan menurunkan kandungan asam humat tanah gambut. Kenaikan nilai $\mathrm{pH}$ tanah gambut sebesar 2,3 satuan $\mathrm{pH}$ setelah penambahan fly ash $200 \mathrm{~g} /$ petak, sedangkan penurunan kandungan asam humat sebesar 0,1951 g dimana peningkatan optimum diperoleh pada analisis minggu kesembilan setelah perlakuan.

\section{DAFTAR PUSTAKA}

1. Bappeda TK I Riau, Kebijaksanaan pemerintah dalam pengembangan Gambut di daerah Riau, Pekanbaru, 2004.

2. D. C. Adriano, and J. T. weber, Influence of fly ash on Soil Physical properties and Turgrass establishment, Journal of environmental quality, 30: 596-601, (2001).

3. Noor, Pertanian di lahan Gambut. Kanisius, Jogjakarta, 2002.

4. R. J. Smernik, A new way to use SolidState carbon-13 nuclear magnetic resonance spectroscopy to study the sorption of organic compounds to soil 
organic matter, Journal of environmental quality, 34: 1194-1204, (2005).

5. U. Silins, and R. L. Rothwell, Forest peatland drainage ang subsidence affect soil water retention and transport properties in an Alberta peatland, Soil Science Society of America Journal, 62: 1048-1056, (1998).

6. T. B. Prasetyo, Peningkatan Serapan Fosfat Pada Tanah Gambut melalui Pengendalian Asam-Asam Meracun, dalam Prosiding Seminar HITI di Bogor, 1996.

7. Notohadiprawiro, Tanah dan Lingkungan, Direktorat Jendral Pendidikan Tinggi, Departemen Pendidikan dan Kebudayaan, Jakarta, 1998.

8. D. E Abbott, M. E. Essington, J. T. Ammons, Fly ash and Lime-Stabilized biosolid mixtures in mine spoil reclamation, Journal of environmental quality, 30: 608-616, (2001)

9. S. M. Pathan, L. A. G Aylmore, T. D. Colmer, Properties of several fly ash materials in relation to usea as soil amendments, Journal of environmental quality, 32: 687-693, (2003).

10. Rini, Mukhtar, Rozalinda, Penggunaan Fly ash (Abu Sisa Boiler Pabrik Pulp) dan Dregs (Limbah Bagian Recauticizing Pabrik pulp) untuk meningkatkan Mutu Tanah Gambut, Laporan Penelitian Hibah Pekerti, Universitas Riau, Pekanbaru, 2005.

11. M. Fukushima, K. Nakayasu, S. Tanaka, and H. Nakamura, Chromium (III) binding abilities of humic acids, Analitica chimica acta, 317: 195-206, 1995.

12. T. B. Prasetyo, Peningkatan Serapan Fosfat Pada Tanah Gambut melalui Pengendalian Asam-Asam Meracun, dalam Prosiding Seminar HITI di Bogor, 1996.

13. G. Sun, K. R. Gray, and Biddlestone, Treatment of agriculture and domestic effluent in constructed downflow reed beds employing recirculation, Environmental technology Journal, 19: 529-536, 1998.

14. T. Hartikainen, J. Ruuskanen, M. Vanhatato, and P. J. Martikainen, Removal of ammonia from air by peat biofilter, Environmental technology Journal, 17: 45-53, 1996.

15. A. R. Hill, and M, Cardaci, Denitrification and Organic Carbon Availability in Riparian Wetland Soils and Subsurface Sediments, Soil Sci. Soc. Am. J., 68, (2004).

16. P. Lingga, dan Marsono, Petunjuk Penggunaan Pupuk Penebar Swadaya, Jakarta, 2005.

17. Foth, D. Hendry, Dasar-Dasar Ilmu Tanah, Gajah Mada, University Press, Jogjakarta, 1998.

18. A. I. Amri, dan Rosmimi, Ameliorasi Tanah Gambut dengan Abu Batubara Untuk Pertumbuhan produksi Jagung ( Zea May L), Jurnal Penelitian Media Informasi dan Komunikasi Ilmiah, Lembaga Penelitian Universitas Riau Pekanbaru, XVI(I): 9-13, (2007).

19. N. Hertkorn, A. Permin, I. Perminova, D. Kovalevskii, M. Yudov, V. Petrosyan, and A. Kettrup, Comparative Analysis of Partial Structures of a Peat Humic and Fulvic Acid Using One- and TwoDimensional Nuclear Magnetic Resonance Spectroscopy, Journal of Environmental Quality, 31: 375-387.

20. E. C. Teixeira, J. Samama, and Brun. A, Study of different leaching methods of metallic element from coal fly ash, Environmental technology Journal, 13, 1187-1192, (1992).

21. K. Yonebayashi, Chemical alteration of tropical peat soils as show by waksman proximate analysis and properties of humic acids. In coastal lowland ecosystem in southern Thailand and Malaysia, Ed., K. Kyuma, P. Vijarnsorn and A. Zakaria. Showado-pronting. Co Sakyoku, Kuoto, 1992, 248-260,.

22. K. A. Aronsson and N. G. A Ekelund, Biological Effects of Wood Ash Application to Forest and Aquatic Ecosystems, J. Environ. Qual., 33: 15951605, (2004).

23. K. D. Ritchey, and J. D. Snuffer, limestone, Gypsum and magnesium oxide influence restoration of an abandoned Appalachian pasture, Agronomy Journal, 94: 830-839, (2002). 